\title{
An exon 4 mutation identified in the majority of South African familial hypercholesterolaemics
}

\author{
M J Kotze, L Warnich, E Langenhoven, L du Plessis, A E Retief
}

\begin{abstract}
The prevalence of familial hypercholesterolaemia (FH) is significantly higher in the Afrikaans speaking population (Afrikaners) of South Africa than reported in most other populations. A founder gene effect has been proposed to explain the high FH frequency, implying that the same low density lipoprotein (LDL) receptor gene defect is present in the majority of affected Afrikaners. By using DNA amplification and sequence determination, we have detected a point mutation in DNA from two Afrikaner FH homozygotes. A cytosine to guanine base substitution at nucleotide position 681 of the LDL receptor cDNA results in an amino acid change from aspartic acid to glutamic acid at residue 206 in the cysteine rich ligand binding domain of the LDL receptor. Since three previously mapped transport deficient alleles of the LDL receptor were also traced to cysteine rich repeats of the protein, these results suggest that the mutation is responsible for the receptor defective mutation predominantly found in Afrikaner FH homozygotes. The mutation gives rise to an additional DdeI restriction site in DNA of affected subjects and segregation of the mutation with the disease was confirmed in five large Afrikaner FH families. We predict that $65 \%$ of affected South African Afrikaners carry this particular base substitution. Amplification of genomic DNA, using the polymerase chain reaction method, and restriction enzyme analysis now permit accurate diagnosis of the mutation in subjects with FH.
\end{abstract}

Mutations in the gene for the low density lipoprotein (LDL) receptor cause familial hypercholesterolaemia (FH), a common autosomal dominant disease. ${ }^{1}$

MRC Cytogenetics Research Unit, Department of Human Genetics, Faculty of Medicine, University of Stellenbosch, PO Box 63, Tygerberg 7505, South Africa.

M J Kotze, L Warnich, E Langenhoven, L du Plessis, A E Retief

Correspondence to Professor Retief.

Received for publication 18 September 1989.

Revised version accepted for publication 26 October 1989.
Subjects inheriting two mutant LDL receptor genes (FH homozygotes) have no normal receptors and their cholesterol levels are about four times the normal. Coronary artery atherosclerosis usually manifests before the age of 10 in homozygotes and they frequently suffer heart attacks in childhood. In FH heterozygotes inheriting one mutant gene, only half of the LDL receptors are normal, resulting in reduced clearance of LDL from the circulation. Plasma concentrations of LDL are approximately twice the normal value in these patients and they typically suffer heart attacks in their fourth to seventh decade of life.

The prevalence of heterozygous $\mathrm{FH}$ appears to be approximately 1 in 500 among the general population of most countries, ${ }^{1}$ but in the South African Afrikaans speaking population (Afrikaners), however, FH occurs at a five to 10 times higher frequency. ${ }^{2} \mathrm{LDL}$ receptor studies of South African FH homozygotes have shown a predominance of a receptor defective mutation of the 'slow maturation' type ${ }^{3}$ and this finding correlates with a founder gene effect. ${ }^{4}$ A similar mutation appears to be responsible for the disease in the Watanabe heritable hyperlipidaemic (WHHL) rabbit and an FH family and in both gene defects were identified in exon 4 of the LDL receptor gene. ${ }^{56}$

The analysis of LDL receptor gene mutations at the molecular level was made possible by the cloning of the normal LDL receptor gene $e^{78}$ and the availability of cloned gene probes. A study of restriction fragment length polymorphism (RFLP) haplotype associations at the LDL receptor gene locus in Afrikaner FH families has shown a predominant association of two haplotypes with the disease. ${ }^{910}$ In $70 \%$ of FH families studied, the defective gene cosegregated with the rare allele of a NcoI RFLP, ${ }^{11}$ while the rare allele of a StuI RFLP ${ }^{12}$ segregated with FH in $20 \%$ of the families. This association was further confirmed by haplotype studies in 27 unrelated FH homozygotes. Twentyfour were homozygous for the NcoI haplotype, while three were heteroallelic for the NcoI and StuI haplotypes.

We recently reported on two LDL receptor gene mutations associated with $\mathbf{F H}$ in a number of Afrikaner $\mathrm{FH}$ patients. ${ }^{1314} \mathrm{~A}$ guanine to adenine base substitution in exon 4 seemed to be the molecular 
defect in FH patients with the associated rare StuI allele. The second mutation, a guanine to adenine base transition in exon 9, was identified in $\mathbf{F H}$ homozygotes with the $N c o$ I associated haplotype. In screening for these mutations in Afrikaner $\mathrm{FH}$ patients, it was observed that in at least half of the patients these mutations were not present. We consequently used the polymerase chain reaction $(\text { PCR })^{15}$ method to amplify genomic DNA from an FH homozygote, homoallelic for the NcoI associated haplotype but normal for the mutation in exon 9 , to permit analysis of these sequences without previous cloning. Direct DNA sequence analysis of the PCR amplified DNA showed a point mutation at the $3^{\prime}$ end of exon 4 in the LDL receptor gene. Segregation of the mutation with the disease was confirmed in five FH families. Restriction enzyme analysis of genomic DNA, enzymatically amplified using synthetic oligonucleotides specific for exon 4 , now permits accurate diagnosis of this mutation in affected subjects.

\section{Materials and methods}

SUBJECTS

The homozygous and heterozygous $\mathrm{FH}$ patients and normocholesterolaemic subjects studied have been described previously. ${ }^{9}{ }^{10}$ DNA sequence analysis was performed in two clinical FH homozygotes (FH 840 and 835), homoallelic for the NcoI haplotype. Pedigree analyses were performed in five $\mathrm{FH}$ families in whom the rare allele of the NcoI RFLP segregates with the disease. Methods used in determination of lipoproteins and preparation of DNA have been described elsewhere. ${ }^{9}$

DNA SEQUENCING OF INTRON 4 ( $5^{\prime}$ END)

To PCR amplify exon 4 from the $5^{\prime}$ to $3^{\prime}$ end for DNA sequence analysis, we needed oligonucleotide primers flanking the exon. The dideoxy chain terminating method $^{16}$ and oligonucleotide primer $T$ (see below) were used to sequence the $5^{\prime}$ end of intron 4 in the recombinant clone lambda $\mathrm{FH} 8-30 .{ }^{17}$ The sequence data were used for the synthesis of oligonucleotide primer $\mathrm{U}$ (see below).

\section{DNA AMPLIFICATION}

The following oligonucleotide primers were synthesised (Beckman Instruments) for amplification of exon 4 of the LDL receptor gene:

5' to 3': 5'-CATCCATCCCTGCAGCCCCC-3' $3^{\prime}(\mathrm{H})$
5' to 5': 5'-GGACTGCGAAGATGGCTCGGA-3'(T)
3' $^{\prime}$ 'GGACCAGGGACAGGTGATAGGAC-3' (U).

Genomic DNA amplification with the Taq polymerase (Amersham International) was performed according to a modification of the procedure described by Saiki et al. ${ }^{18}$ Target sequences were amplified in 1 $\times$ reaction buffer $(10 \times$ buffer: $10 \mathrm{mmol} / 1$ Tris- $\mathrm{HCl}$, pH $8.3,50 \mathrm{mmol} / 1 \mathrm{KCl}, 1.5 \mathrm{mmol} / 1 \mathrm{MgCl}_{2}, 0.01 \%$ (w/v gelatine) in a $100 \mu \mathrm{l}$ reaction volume containing 1 $\mu \mathrm{g}$ of genomic DNA, $0.2 \mathrm{mmol} / \mathrm{l}$ each deoxyadenosine triphosphate, deoxycytosine triphosphate, deoxyguanosine triphosphate, and deoxythymidine triphosphate, and 100 pmol of each oligonucleotide primer. Samples were covered with a drop of mineral oil, heated at $96^{\circ} \mathrm{C}$ for 10 minutes to denature the DNA, and allowed to cool at $56^{\circ} \mathrm{C}$ for one minute. One unit of $T a q$ polymerase was added to each sample which was then transferred to $72^{\circ} \mathrm{C}$ for two minutes for primer directed DNA synthesis. Subsequent rounds consisted of a one minute denaturation step at $92^{\circ} \mathrm{C}$, a one minute primer annealing step at $55^{\circ} \mathrm{C}$, and an extension step at $72^{\circ} \mathrm{C}$ for two minutes. A total of 35 cycles was performed in a Hybaid heating block.

The PCR products from DNA of FH patients and control subjects were used for either direct DNA sequencing or restriction enzyme analysis.

\section{DNA SEQUENCING OF PCR AMPLIFIED DNA}

DNA fragments were sequenced by the dideoxy chain termination method, ${ }^{16}$ using the above oligonucleotide primers specific for exon 4 and a commercial kit (Taq Track, Promega). The sequences obtained in FH homozygotes were compared to sequence data from normal control subjects and the sequence published for exon 4 of the LDL receptor gene.?

RESTRICTION ENZYME ANALYSIS OF PCR AMPLIFIED DNA Aliquots $(50 \mu \mathrm{l})$ of the DNA samples, amplified with primers $\mathrm{T}$ and $\mathrm{U}$, were digested with five units of $D d e I$, subjected to gel electrophoresis in $8 \%$ polyacrylamide gels, and visualised by ultraviolet fluorescence after staining with ethidium bromide. The sizes of the resultant DNA fragments after DdeI digestion were deduced by comparison with a standard marker (0174 DNA digested with HaeIII).

\section{Results}

DNA SEQUENCING

Sixty nucleotides at the $5^{\prime}$ end of intron 4 were sequenced in a recombinant clone lambda FH 8-30, ${ }^{17}$ containing exons 4 to 11 of the LDL receptor gene. The sequence obtained was used for the synthesis of oligonucleotide primer U (5'-GGGACCCAGGG ACAGGTGATAGGAC-3'). PCR amplification of exon 4 sequences from genomic DNA of two FH homozygotes, using oligonucleotides $U$ and $H^{8}{ }^{8}$ produced a 450 bp DNA fragment. Direct DNA sequence analysis of the fragment using oligonucleotide $T$, specific for the middle portion of exon $4,^{7}$ 

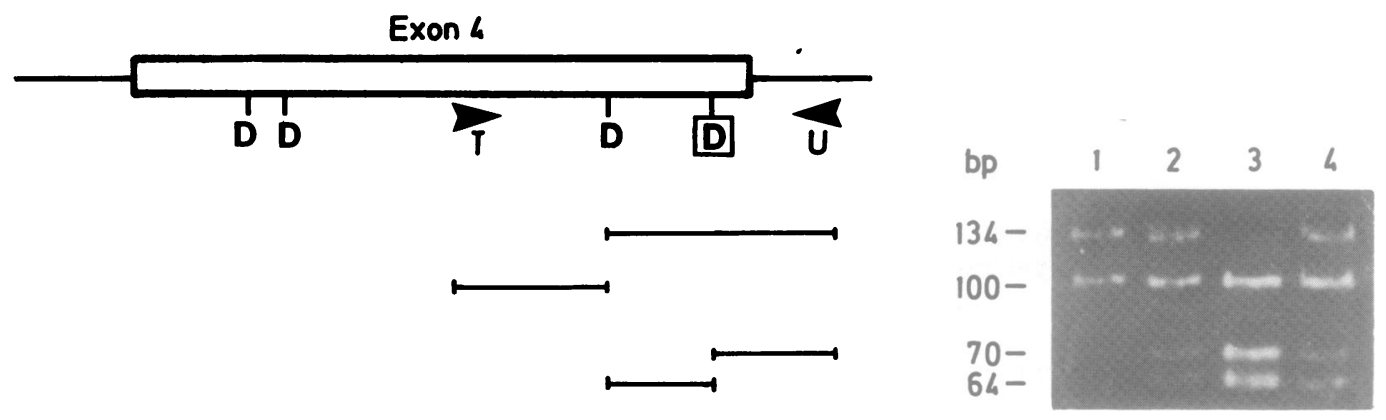

Figure 1 Gel electrophoresis of DdeI digested, PCR amplified exon 4 DNA. Lanes: (1)DNA from a normal control. (2) DNA from an FH heterozygote. (3) DNA from a homoallelic FH homozygote. (4) DNA from a heteroallelic FH homozygote.

showed a single base substitution at the $3^{\prime}$ end of exon 4 in the LDL receptor gene. A cytosine was replaced by a guanine at nucleotide position 681 in the $\mathrm{FH}$ patients, changing amino acid 206 from aspartic acid to glutamic acid. The mutation was observed by comparing the sequence data of exon 4 in the affected subjects with the sequence published for the LDL receptor $\mathrm{cDNA}^{7}$ and the sequences obtained in normal controls. From these data we deduced that the substitution of a guanine for a cytosine will result in an additional DdeI restriction endonuclease recognition site in mutated alleles of affected subjects.

\section{ANALYSIS OF DdeI DIGESTED GENOMIC DNA}

Fig 1 illustrates DNA restriction patterns after DdeI digestion of PCR amplified genomic DNA (using oligonucleotides $\mathrm{T}$ and $\mathrm{U}$ ) and gel electrophoresis of the products. The digestion of DNA from a normal control subject resulted in fragments of 100 and 134 bp (lane 1). The presence of an additional DdeI restriction site in the mutated allele was confirmed in DNA from an FH homozygote, where the 134 bp fragment was cleaved into two fragments of 64 and 70 bp (lane 3). DNA from an FH heterozygote (lane 2) or a heteroallelic FH homozygote (lane 4) shows the constant $100 \mathrm{bp}$ fragment, together with the $134 \mathrm{bp}$, $70 \mathrm{bp}$, and $60 \mathrm{bp}$ fragments, indicating heterozygosity for the exon 4 mutation.

\section{ANALYSIS OF THE MUTATION IN NORMAL AND FH FAMILIES}

The mutation at the $3^{\prime}$ end of exon 4 in the LDL receptor gene was studied in five informative $\mathrm{FH}$ families (15 normal and 23 affected offspring). The presence of the mutation, as seen by an additional $D d e I$ restriction site in the amplified DNA of affected subjects, correlates with high LDL cholesterol levels in these patients. An example of one family is shown in fig 2. These data, together with the absence of the

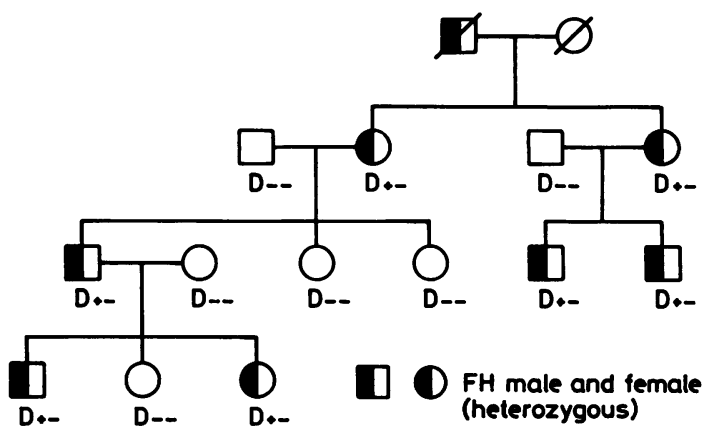

Figure 2 Segregation of $F H$ and the mutant allele of the $L D L$ receptor gene in a family with the disease. PCR amplified DNA from family members was digested with $D$ deI $(D)$ and electrophoresed in $8 \%$ polyacrylamide gels. The normal allele is indicated by the absence $(-)$ of a DdeI restriction site and the mutant allele by the presence $(+)$ of the site.

mutation in 12 unrelated normal subjects, suggest that the exon 4 mutation causes the disease in the affected family members.

\section{FREQUENCY OF THE MUTATION IN FH PATIENTS}

To estimate the frequency of the $3^{\prime}$ end exon 4 mutation among Afrikaner FH heterozygotes, we screened DNA samples from 40 unrelated subjects who were classified clinically as having the heterozygous form of $\mathrm{FH} .{ }^{9}$ Of these, 26 were found to have the mutation, indicating that approximately $65 \%$ of Afrikaner FH heterozygotes have this particular LDL receptor gene mutation. The predominance of the $3^{\prime}$ end exon 4 mutation in Afrikaner FH patients was further confirmed by restriction enzyme analysis of DNA from 26 FH homozygotes. Of these 'unrelated' homozygotes who were screened, 13 were found to have the mutation in the heterozygous form, while 10 were homozygous for the mutation $(63 \%$ of the alleles studied). Although the founder origin for $\mathrm{FH}$ among 
Afrikaners ${ }^{4}$ implies that affected subjects could have been related many years ago, none of the family units studied was known to be related at the level of first or second cousins.

\section{Discussion}

At least four different classes of LDL receptor gene mutations, based on measurements of LDL receptors found on the surface of cultured fibroblasts, can be distinguished. ${ }^{19}$ In the first receptor negative class, the mutant gene fails to synthesise functional LDL receptor proteins. In class 2 mutations, the defective receptors are synthesised, but are not processed to the mature form or transported to the cell surface. Class 3 mutations are those in which the receptors fail to bind LDL normally and class 4 mutations encode internalisation defective $L D L$ receptors. A variant of the class 2 mutation, which produces receptors that are converted to the mature form at an abnormally slow rate, has been identified in WHHL rabbits and in several FH homozygotes, ${ }^{5}$ including three South Africans. ${ }^{319}$ Yamamoto et al ${ }^{6}$ reported that the gene mutations in both the WHHL rabbits and an FH patient with the variant receptor defective mutation involve small in frame deletions in exon 4 of their LDL receptor genes. Exon 4 of the LDL receptor gene was subsequently selected for analysis because of the presence of these known mutations in the cysteine rich region of the gene that cause disruption of LDL receptor transport to the plasma membrane.

In order to amplify exon 4 from the $5^{\prime}$ to $3^{\prime}$ end using the PCR method, oligonucleotide primers outside the coding sequence were needed. The sequence for the synthesis of the $3^{\prime}$ end oligonucleotide primer was obtained by sequencing 60 nucleotides at the $5^{\prime}$ end of intron 4 in the genomic clone lambda FH 8-30. ${ }^{17}$ PCR amplification and sequencing of genomic DNA from two FH homozygotes, using the $3^{\prime}$ and $5^{\prime}$ end ${ }^{8}$ oligonucleotide primers for exon 4 of the LDL receptor gene, detected a cytosine to guanine base substitution at nucleotide position 681 of the cDNA. This mutation was found in $65 \%$ of Afrikaner FH heterozygotes and occurred in the homozygous form in 13 patients from 10 different families. In total, 92 defective LDL receptor genes were analysed in the Afrikaner FH population, of which $59(64 \%)$ show the $3^{\prime}$ end exon 4 mutation. Studies are currently under way to determine the population frequencies of the mutations in exon 9 and the middle portion of exon $4^{13} 14$ in the remaining Afrikaner FH patients.

The above results indicate that the $3^{\prime}$ exon 4 point mutation accounts for the majority of LDL receptor gene mutations among the Afrikaans speaking FH population in South Africa. The cytosine to guanine base substitution at nucleotide position 681 , resulting in a substitution of a glutamic acid for an aspartic acid at residue 206, has so far not been observed in any other ethnic group. Although it remains to be investigated whether this amino acid change in exon 4 causes a similar transport deficient mutation, as was described for the exon 4 deletions in WHHL rabbits and FH patients, ${ }^{56}$ it may be expected to represent the receptor defective mutation predominantly found in Afrikaner FH homozygotes. ${ }^{3} 19$ To date three of the four transport deficient alleles described at the LDL receptor gene have been traced to cysteine rich repeats of the protein. ${ }^{62021}$ The mutation described in this study does not remove any of the cysteine residues in the LDL receptor protein, but its presence is likely to have a marked effect on the folding pattern of the cysteine rich domain, in such a way that the formation of proper disulphide bonds are prevented. Although it is at present not clear whether the aspartic acid to glutamic acid change at residue 206 is directly related to the functional defect of the LDL receptor in subjects with the mutant allele, family studies on the segregation of this allele strongly suggest that the mutation in exon 4 causes the disease in affected family members. However, recreation of the mutation in expressible cDNAs and transfection studies will be necessary to confirm that the mutation results in an abnormally processed receptor protein.

The identification in Afrikaner FH patients of the point mutation at the $3^{\prime}$ end of exon 4 , together with those in exon 9 and the middle of exon 4,1314 indicates that the high frequency of FH in South Africa is caused by three founder genes. Amplification of genomic DNA from blood and tissue samples by the PCR method, using synthetic oligonucleotides specific for exons 4 and 9, now permits accurate diagnosis of these mutations by restriction enzyme analysis. It will also be possible to use this method to screen unselected subjects of Afrikaner ancestry to determine the frequencies of these mutations in the population.

We thank Professors H F H Weich, H C Seftel, and G M B Berger and Dr H E Henderson for inclusion in the study of $\mathrm{FH}$ patients attending the lipid clinics at Tygerberg, Johannesburg, Groote Schuur, and Red Cross Children's Hospitals. This work was supported by the South African Medical Research Council, the University of Stellenbosch, and the Cape Provincial Administration. The work is part of a thesis to be submitted in fulfilment of the requirements for the degree of Doctor of Philosophy, University of Stellenbosch.

1 Goldstein JL, Brown MS. Familial hypercholesterolaemia. In: Stanbury JB, Wyngaarden JB, Frederickson DS, Goldstein JL, Brown MS, eds. The metabolic basis of inherited disease. 5th ed. New York: McGraw-Hill, 1983:672-712.

2 Jooste PL, Benade AJS, Rossouw JE. Prevalence of familial hypercholesterolaemia in three rural South African communities. $S$ Afr Med F 1986;69:548-51.

3 Van der Westhuizen DR, Coetzee GA, Demasius IPC, et al. Low density lipoprotein receptor mutations in South African homo- 
zygous familial hypercholesterolaemic patients. Arteriosclerosis 1984;4:238-47.

4 Seftel HC, Baker SG, Sandler MP, et al. A host of hypercholesterolaemic homozygotes in South Africa. $\mathrm{Br} M e d \mathcal{J}$ 1980;28: 633-6.

5 Schneider WJ, Brown MS, Goldstein JL. Kinetic defects in the processing of the LDL receptor in fibroblasts from WHHL rabbits and a family with familial hypercholesterolemia. Mol Biol Med 1983;1:355-67.

6 Yamamoto T, Bishop RW, Brown MS, Goldstein JL, Russell $\mathrm{DW}$. Deletion in cysteine-rich region of $\mathrm{LDL}$ receptor impedes transport to cell surface in WHHL rabbit. Science 1986;232: 1230-7.

7 Yamamoto T, Davis CG, Brown MS, et al. The human LDL receptor: a cysteine-rich protein with multiple Alu sequences in its mRNA. Cell 1984;39:27-38.

8 Südhof TC, Goldstein JL, Brown MS, Russell DW. The LDL receptor gene: a mosaic of exons shared with different proteins. Science 1985;228:815-22.

9 Kotze MJ, Langenhoven E, Retief AE, et al. Haplotype associations of three DNA polymorphisms at the human low density lipoprotein gene locus in familial hypercholesterolaemia. f Med Genet 1987;24:750-5.

10 Kotze MJ, Langenhoven E, Retief AE, et al. Haplotypes identified by 10 DNA restriction fragment length polymorphisms at the human low density lipoprotein receptor locus. f Med Genet 1989;26:255-9.

11 Kotze MJ, Langenhoven E, Dietzsch E, et al. A RFLP associated with the low-density lipoprotein receptor gene. Nucleic Acids Res 1987;15:376.
12 Kotze MJ, Retief AE, Brink PA, et al. A DNA polymorphism in the human low-density lipoprotein receptor gene. $S$ Afr Med $f$ 1986;77:77-9.

13 Retief AE, Kotze MJ, Oosthuizen CJJ. Identification of gene mutations allows for the molecular diagnosis of familial hypercholesterolaemia. S Afr Med F 1989;76:121.

14 Kotze MJ, Langenhoven E, Warnich L, et al. The identification of two LDL-R gene mutations in South African familial hypercholesterolaemia. S Afr Med f 1989;76:399-401.

15 Mullis KB, Faloona FA. Specific synthesis of DNA in vitro via a polymerase-catalyzed chain reaction. Methods Enzymol 1987; 155:335-49.

16 Sanger F, Nicklen S, Coulson AR. DNA sequencing with chainterminating inhibitors. Proc Natl Acad Sci USA 1977;74: 5463-7.

17 Kotze MJ, Langenhoven E, Warnich L, et al. Molecular characterisation of a low-frequency mutation in exon 8 of the human low-density lipoprotein (LDL) receptor gene. S Afr Med 7 1989;76:402-5.

18 Saiki RK, Gelfand DH, Stoffel S, et al. Primer-directed enzymatic amplification of DNA with a thermostable DNA polymerase. Science 1988;239:487-91.

19 Goldstein JL, Brown MS. Progress in understanding the LDL. receptor and HMG-CoA reductase, two membrane proteins that regulate the plasma cholesterol. F Lipid Res 1984;25:1450-61.

20 Lehrman MA, Schneider WJ, Brown MS, et al. The Lebanese allele at the low density lipoprotein receptor locus. F Biol Chem 1987;262:401-10.

21 Esser V, Russell DW. Transport-deficient mutations in the lowdensity lipoprotein receptor. $\mathcal{F}$ Biol Chem 1988;263:13276-81. 